\title{
Evidence for insertional codemixing: mixed compounds and French nominal groups in Brussels Dutch
}

Article

Accepted Version

paper

Treffers-Daller, J. (2005) Evidence for insertional codemixing: mixed compounds and French nominal groups in Brussels Dutch. International Journal of Bilingualism, 9 (3-4). pp. 477506. ISSN 1756-6878 doi:

https://doi.org/10.1177/13670069050090030901 Available at https://centaur.reading.ac.uk/29893/

It is advisable to refer to the publisher's version if you intend to cite from the work. See Guidance on citing.

To link to this article DOI: http://dx.doi.org/10.1177/13670069050090030901

Publisher: Sage

All outputs in CentAUR are protected by Intellectual Property Rights law, including copyright law. Copyright and IPR is retained by the creators or other copyright holders. Terms and conditions for use of this material are defined in the End User Agreement.

www.reading.ac.uk/centaur 
Central Archive at the University of Reading

Reading's research outputs online 
Evidence for insertional code-mixing: mixed compounds and French nominal groups in Brussels Dutch ${ }^{1}$

International Journal of Bilingualism, special issue on code-switching and language change (2005). Editors: A.Backus, J.Nortier and J. Treffers-Daller

Jeanine Treffers-Daller (UWE, Bristol)

\section{Abstract}

In this paper we analyse mixed compounds, such as legume+winkel 'vegetable shop, greengrocery' and winter+paletot 'winter coat' which contain a French and a Dutch element, and French nominal groups, such as carte d'identité 'identity card', and journal parlé 'radio news', which bilingual speakers from Brussels frequently insert into Brussels Dutch utterances. Using Muysken's (2000) typology of bilingual speech, we claim that the mixed compounds and the nominal groups display the characteristics of insertional code-mixing. In addition, some evidence for the existence of a continuum between borrowing and code-switching can be obtained from these examples. As the multimorphemic units that are inserted into Dutch are neither single words, nor full constituents, their status in the lexicon raises interesting issues for researchers interested in the interface between syntax and the lexicon (see also Backus 2003). We try to argue that nominal groups such as carte d'identité and journal parlé are probably best seen as lexical templates or constructional idioms (Booij, 2002b). The insertion of French constructional idioms in Brussels Dutch represents an innovation in the lexical patterns that are available to speakers of this language, which is highly relevant for theories of language change.

\footnotetext{
${ }^{1}$ I am very grateful to Ad Backus, Kate Beeching, Geert Booij, Sera de Vriendt, Adrienne Mason, Pieter Muysken, Jacomine Nortier, Michael Picone, Rodney Sampson and Wiecher Zwanenburg for their comments on earlier versions of this paper. Any imperfections remaining are the result of mine.
} 
Keywords: borrowing, code-mixing, constructional idioms, Dutch, French, language contact

0. Introduction

This article focuses on two types of French elements in Brussels Dutch ${ }^{\mathrm{i}}$ that have so far received relatively little attention in the literature on French-Dutch language contact. First of all, we will be studying mixed nominal compounds, such as legume+winkel 'vegetable shop' and winter+paletot 'winter coat', which consist of a French element on the left and a Dutch element on the right, or vice versa ${ }^{\mathrm{ii}}$. Second, we will consider nominal groups, such as carte d'identité 'identity card' and sense unique 'one-way street' in Brussels Dutch, which consist of French words only. These insertions differ from what M'Barek and Sankoff (1988) have called constituent insertions, in that they are not accompanied by French determiners, as can be seen in (1) - (3).

(1) Ik neem ook geen carte d'identité meer mee (tape 3:2, Marie)

I take also no card of identity more with

"I do not take an identity card with me anymore."

(2) Ze

hadden bijeengelegen en

mij een schoon presse-casserole $e^{i i i}$ They had together-put and me a nice pressure cooker

gekocht

bought (tape 50: 13, Linda)

"They had put some money together and bought me a nice pressure cooker."

(3) Weet ge, als er ene uit ne sens unique komt Know you, if there one from a one-way street comes...

"You know if there is one coming from a one-way street..." ...(tape 64: 11, Wilfried) 
It is only when a Dutch determiner is added to these insertions that they become complete Determiner Phrases (DPs). Thus, they are something in between a noun $\left(\mathrm{X}^{0}\right)$ and a complete phrase $\left(X^{\max }\right)$. In Muysken's (2000: 61) classification of nominal insertions, the examples in (1) - (3) fall in the category of NP insertions, that is insertions of adjective + noun or noun + complement. As NPs are sometimes understood to refer to full phrases (with a determiner), we will not use the term NP insertion here. Instead we will use the term nominal groups, as is common in much of the French literature on the topic.

Several authors (Gross, 1996; Noailly, 1990) have noted interesting similarities and differences between compounds and nominal groups or between different types of nominal groups ( $\mathrm{N}+\mathrm{PP}$ and $\mathrm{N}+\mathrm{A}$ for example). In fact, in many cases compounds and nominal groups represent alternative ways of expressing the same concepts (see below for more details). Studying both constructions in one paper therefore seems entirely appropriate.

One reason to study mixed compounds and nominal groups such as carte d'identité is that they can shed new light on the characteristics of different types of codemixing as distinguished by Muysken (2000), and on the similarities and differences between different language contact phenomena. Many researchers have tried to identify the differences between code-switching and borrowing. All models which are based on the binary distinction between code-switching and borrowing, to begin with the groundbreaking study of Poplack (1980), which was elaborated in many follow-up studies (Poplack \& Meechan,1995; Sankoff, Poplack \& Vanniarajan, 1990) and MyersScotton's (1993) highly influential Matrix Language-Frame Model (MLF model), which was subsequently elaborated in various papers, have struggled with a range of phenomena which appear to be difficult to classify in one or the other category. It is for that reason that Picone (1994) proposes that we have to allow for the possibility of regular code-intermediate phenomena that escape such classifications. Similar ideas have been advanced by Clyne (1987) and Muysken $(1987,2000)$ who show how elements that can belong to either language can serve as neutralization sites at which mixing is facilitated.

In this paper we hope to present some evidence for a different analysis, based on Muysken's typology of code-mixing, in which the mixed compounds and the nominal 
groups in (1) - (3) are seen as examples of insertional code-mixing. This type of codemixing comprises phenomena other researchers have called borrowing, nonce borrowing and constituent insertion. The following criteria are used to identify insertional codemixing (Muysken, 2000: 62):

a) The elements that are inserted form a constituent together.

b) The insertions exhibit a nested $\mathrm{a} b$ a structure, that is the fragment preceding the insertion and the fragment following the insertion are grammatically related.

c) The switched elements tend to be content words rather than function words.

d) Insertions are often selected elements (objects or complements) rather than adjuncts.

e) Insertions are often morphologically integrated.

In section 4 we hope to show to what extent mixed compounds and insertions of nominal groups, as exemplified in (1) - (3), can be considered as insertional code-mixing, given the criteria listed here.

Another reason why compounds and nominal groups such as carte d'identité are interesting is that they can illustrate the similarities and the differences between words and phrases. Nominal groups are special because they have some morphological characteristics of compounds and some properties of phrases, as we will see below. Following Booij (2002b: 302), we will argue that nominal groups are probably best seen as lexical templates or constructional idioms, i.e. "syntactic constructions with a partially or fully noncompositional meaning contributed by the construction, in which - unlike idioms in the traditional sense - only a subset (possibly empty) of the terminal elements is fixed." We hope to show that an analysis of nominal groups in a bilingual context can contribute to a further understanding of the role of constructional idioms in language change.

Nominal groups such as carte d'identité have received a lot of attention in the French literature. While some authors (e.g. Gross, 1996) consider them as compounds, others (e.g. Zwanenburg, 1992a) do not. To some extent, these differences can be explained by the fact that authors use different definitions of compounds, and we will be 
looking into that in more detail below. According to several authors (Grevisse, 1993: 237; Sadock, 1998: 169), nominal compounding is not productive in French (but see below for more discussion): instead the functions fulfilled by compounds are often expressed in French in the form of a syntactic phrase which may or may not be fixed. In many cases these phrases are nominal groups which consist of a noun and a prepositional phrase. In English, as in Dutch, it is possible to express the function "modifier modified" in the form of a compound, such as mountain top or in the form of a phrase, such as top of the mountain (Sadock, 1998). In French various types of phrases are used and these will be discussed below. The differences between French and Dutch become clear when translating Dutch nominal compounds into French: the compounds are often translated as syntactic phrases. Thus, for example, kuis+vrouw and stoom+tram are the (Southern) Dutch translation equivalents of femme d'ouvrage and tram-à-vapeur respectively, and the compounds legume+winkel and winter+paletot can be translated in French as phrases consisting of a noun + prepositional phrase: marchand de légumes $^{\text {iv }}$ and manteau d'hiver respectively. It is new, to my knowledge, to analyse these constructions from the perspective of language contact between two languages, such as French and Dutch. As these languages have very different rules for the formation of compounds and phrases, studying the way these mixed compounds are formed and are integrated into the matrix or host language can add a new dimension to the research carried out so far.

The literature which deals with general aspects of word formation (DiSciullio and Williams, 1987) or which focuses in more detail on compounds (Gross, 1996; Sadock, 1998; Zwanenburg, 1992a, 1992b) does not pay attention to mixed compounds. In the literature on language contact, on the other hand, several authors have focussed on mixed compounds, but here the main focus is on verbal compounds rather than on nominal compounds (Muysken, 1992, 2000; Romaine, 1989). An exception is Clyne (1967: 34; in Muysken, 2000: 150), who gives several examples of nominal hybrid compounds such as beach-häuser 'beach houses' and Ketten-store 'chain store'. Mixed compounds are particularly interesting because the complexities of the compounding process are augmented by the fact that in mixed compounds two different grammars interact. 
As the rules for the formation of compounds are very different in French and in Dutch (see below for more details), theories based on linear equivalence, such as the Equivalence Constraint (Poplack, 1980) would predict that it should be very difficult, if not impossible, to construct hybrid compounds with a French and a Dutch element in it, as there is little linear equivalence between the two languages on this point. For theories based on insertions of guest language material into a host language structure, such as Myers-Scotton's (1993) Matrix Language Frame model and its successors, mixed compounds are perhaps less problematic, as Embedded Language elements can be integrated in various ways into a Matrix Language structure.

In order to find out whether examples (1) - (3) and mixed compounds should be seen as insertions (Muysken, 2000), we will need to answer the question whether the grammars of both languages play an equally important role in these constructions or whether one of them (the host or matrix language) actually defines the grammatical frame in which the French elements are integrated. Therefore we will look at word order and at the morphological shape of the elements within the compounds and the nominal groups. In addition, occasionally semantic or phonetic issues may be addressed. The main focus will however be on syntax and morphology.

Before answering these questions we will look at different definitions of compounds and we will give an overview of the major differences between the rules for the formation of compounds in French and in Dutch (section 2). In section 3, we will analyse the data from our corpus ${ }^{\mathrm{v}}$ and in the final section we will try to draw conclusions in relation to the questions formulated above.

\section{Compounding in French and Dutch}

According to Grevisse (1993: 233), “on appelle composition le procédé par lequel on forme une nouvelle unité lexicale en unissant deux mots existants." In many languages, the constituent parts of the compounds are free morphemes, as Bloomfield (1933: 227) observes. Zwanenburg (1992a) however shows that in French there are examples of learned compounds such as aérodrome 'areodrome' and hétérodoxe 'heterodox', which consist of two bound morphemes, and the same analysis can be applied to compounds in 
other languages. Therefore Booij (2002a: 141) proposes that "the defining criterion for compounding as opposed to derivation is that in compounding two lexemes are combined into a new lexeme."

While most authors would agree with these statements, defining compounds remains very difficult, and exceptions can be found to most properties generally considered to be typical of compounds. According to Sadock (1998) compounding is an autonomous process that cannot be reduced to either syntactic or morphological or semantic phenomena. For Bisetto and Scalise (1999), the main test of compoundhood has always been the impossibility of inserting phonologically realised material between the constituents. Thus, uomo rana 'frog man' is a true compound because it is impossible to insert piccolo between the two elements, as is shown in (4).

(4) *uomo piccolo rana (Bisetto \& Scalise, 1999: 35)

man little frog (lit.)

"little frog man"

Bisetto and Scalise present other syntactic tests which can show that compounds are syntactically opaque or "syntactic atoms". Having tried these out on Italian data, they come to the conclusion that compound-like phrases in Italian are similar to compounds on three of the five tests they apply. Thus, the results are far from conclusive. Given the range of criteria that are involved in the definition of compounding, the best approach is probably that of Gross (1996: 16), who proposes that there are relative rather than absolute differences between compounds and phrases, and that individual items can display all, some or no characteristics of compounds.

The phenomenon of compounding has received a lot of attention in French, starting with the seminal work of Darmesteter (1874). It is somewhat difficult to summarise the discussion, because work done by authors outside France and in languages other than French do not appear to have been incorporated in the French discussion, and apart from exceptions such as Picone (1996) - the anglophone literature is often unaware of discussions in France (see also Posner's (1997) comments on the contrast between Anglo-Saxon and Continental European studies on French). A good overview of work 
done so far in French (and on French) can be found in Gross (1996). Some French authors have mainly focused on semantic properties of compounds, such as the semantic relations between the different parts of the compounds, while others are most interested in their grammatical properties, and in the similarities and differences between compounds and other nominal groups (whether or not lexicalised). The latter approach appears to be most relevant for our analysis.

In this paper we concentrate on nominal compounds as these are the most productive type of compounds in standard Dutch (Booij, 2002a: 142), as well as in the Brussels Dutch corpus we are currently analysing.

French and Dutch have very different morphological and syntactic rules for the formation of compounds ${ }^{\mathrm{vi}}$. An overview of the differences is given in table 1, and each aspect is discussed at some length in the following sections.

- insert Table 1 about here -

\subsection{Word order inside compounds}

In Dutch word order inside nominal compounds is very different from that of the corresponding syntactic phrase, as the following examples illustrate. In (5) we see the word order found in compounds, where two modifying morphemes precede the head, and in (6) the order of the corresponding syntactic phrase, where one modifying prepositional phrase follows the head.

5) het woon+werk+verkeer

the live + work + traffic

'commuter traffic'

6) het verkeer tussen woonplaats en werk

the traffic between hometown and work

'commuter traffic' 
In French, on the contrary, word order inside many compound-like items is generally the same as that of syntactic phrases, as we can see by comparing (7a) and (7b) as well as (8a) and (8b), in which the same lexical items are used in a syntactic phrase.

(7a) peau rouge 'lit. skin red, red skin' (compound-like construction)

(7b) peau bronzée 'lit. skin tanned, tanned skin' (free NP)

(8a) brise-glace 'lit: break-ice, ice breaker' (compound-like construction)

(8b) (Elle) brise la glace '(She) breaks the ice' (free VP)

A limited number of fixed expressions, such as rouge-gorge 'robin' and Blanche-neige 'Snow white' have a different word order, namely A+N.

Zwanenburg (1992b) shows that in Old French, which was head-final, one can find more examples of right-headed compounds than in Modern French. An example is chèvre-feuille 'lit. goat leaf, honeysuckle'. In learned words, such as agriculture 'agriculture' and autostrade 'motorway', the head is almost always the element on the right-hand side. Thus, the order modifier-head does exist in French compounds, but its use is limited to learned words and a small number of frozen expressions. For Zwanenburg, the class of real compounds is limited to nouns, adjectives and verbs with a modifying preposition or adverb, such as sous-chef 'lit. under-boss, deputy', bienheureux 'lit. well happy, blessed', and maltraiter 'ill-treat', all of which are right-headed, whereas the other constructions are syntactic phrases, which are left-headed in modern French.

Zwanenburg (1992a: 2) formulates the relationship between the position of the head and the modifier in compounds and in syntax as follows: "dans le cas non-marqué, la composition d'une langue a la tête du même côté que la syntaxe." The same idea can be found in Beard (1996, in Lardière, 1998), who proposes the following explanation of word order inside compounds.

(9) Base Rule Ordering Principle (Beard, 1996: 2; in Lardière, 1998: 288) 
«The subordinate constituent of a compound of category $\mathrm{X}$ assumes the default position, before or after the head, of the adjunct [or complement] in the correlate XP."

For Dutch, this means that the modifier in compounds occupies the same position as adjectives in noun phrases, that is the position before the noun. Thus, in Southern Dutch kuis+vrouw 'cleaning lady' we find the modifier kuis- on the left-hand side of the head vrouw. In French, the default position for modifiers is the position after the noun, which explains why in compounds the modifier is generally found after the noun, as in fait divers 'news in brief'. As many researchers have pointed out, for exocentric compounds, such as peau rouge or porte-manteau the notion of head is problematic, as neither the first nor the second element is directly responsible for all the morphosyntactic properties of the entire word (ten Hacken 2000), nor does the first or the second element function as the head from a semantic point of view.

\subsection{Accents}

In Dutch one of the distinct properties of compounds is the fact that the main stress of compounds falls on the first element, whereas the main stress of the corresponding phrase falls on the second element. Thus, for the compound noun wit+boek 'white paper' the main accent falls on wit-, whereas for the corresponding noun phrase een wit boek 'a white book', the main accent falls on boek. Similar differences exist in English, as one can see in well-known examples such as the White House and a white hóuse. In French, by contrast, there is no systematic difference between the accentuation of compounds and phrases, as Rohrer (1977: 205 et seq) convincingly shows. ${ }^{\text {vii }}$ The main stress falls on the last syllable of a rhythmic group, although there are some exceptions (see Wioland, 1991). Clearly, individual words, compounds or phrases can occupy different positions in a rhythmic group, so stress patterns may vary depending on the position of the compounds or the phrase in the rhythmic group. 


\subsection{Productivity of different types of compounds}

In Dutch, nominal compounding is very productive and new compounds are created on a daily basis. The Brussels Dutch corpus contains many examples of Dutch nominal compounds, most of which consist of two nouns, for example assen+bak 'ashtray' and pjêre+pansj 'horse bladder'. Booij (2002a: 142) show that a range of different categories can function as the left-hand element of compounds, but only nouns and adjectives can function as the right-hand element (the head) of compounds in Dutch, and this is true for Brussels Dutch too, as far as we know.

According to Grevisse (1993) and Sadock (1998), N+N compounding is not productive in French (but see below for prepositionless combinations of two nouns). There are only a few 'real compounds' or mots composés proprement dits in French, which are right-headed according to Zwanenburg (1992a). French makes extensive use of syntactic phrases, many of which consist of a noun followed by a prepositional phrase with or without article. The contrast between the two languages is clearly visible in Brussels street names, for example. In (10)-(13) the French street names are always phrases, whereas the Dutch street names are compounds ${ }^{\text {viii }}$.

(10) Rue des Fabriques - Fabriek+straat

(11) Rue aux Laines - Wol+straat

(12) Avenue de la Pinède - Pijnbos+laan

(13) Avenue de Sumatra - Sumatra+laan

(14) Rue du Cirque - Circusstraat

Gross (1996: 49) claims that nominal groups which consist of a noun followed by a prepositional phrase in de ( $\mathrm{N}$ de $\mathrm{N}$ groups) and nominal groups which consist of a noun, followed by an adjective ( $\mathrm{N}+\mathrm{A}$ groups) are by far the most productive category of compound-like elements in French: Gross gives a figure of 50.000 for $N$ de $N$ groups ${ }^{\text {ix }}$, and 40.000 for $\mathrm{N}+$ A groups, which is based on Mathieu-Colas (1996), who presents a typology of nominal compounds in French. 
This section would be incomplete without any reference to the phenomenon of the substantif épithète, or prepositionless combinations of two nouns, as in (15) - (17), which is currently a very frequent phenomenon in certain registers of French, but which has been found in texts as old as the $14^{\text {th }}$ century (Noailly, 1990).

(15) les vacances neige 'lit. the holidays snow, snow holidays'

(16) le trafic domicile-travail 'lit. the traffic home-work, commuter traffic' (17) une visite éclair 'lit. a visit flash, flying visit' (Noailly, 1990: 43)

On the surface, (15) - (17) look like compounds, but neither Zwanenburg (1992a) nor Noailly consider them as compounds for a number of reasons. While Noailly may be right that prepositionless combinations of two nouns are not necessarily lexicalised, this is not a sufficient argument against considering them as compounds. Booij \& Van Santen (1998) show that Dutch compounds are not always lexicalised either, and Sadock makes the same point for English compounds. It is possible to see the examples in (15) to (17) as mere extensions of the possibilities for adjunction within the noun phrase, which would explain the examples without concluding that they are real compounds.

Noailly (1990) and Picone (1996) show that there are different subtypes among these nominal groups, each of which has different properties. For many of these nominal groups in $\mathrm{N}+\mathrm{N}$ it is true that they share a lot of characteristics with free noun phrases. As we can see in the contrast between (17a) and (18a) it is possible to insert an adverb between the two parts of some $\mathrm{N}+\mathrm{N}$ structures, whereas no intensifier can be inserted between fait and divers, which is much more lexicalised and often considered as a compound. Also, it is possible to find the second noun conjoined with a following adjective, as in (17b), which is impossible in the case of fait divers, as is exemplified in (18b).

(17a) une visite tout à fait éclair (Noailly, 1990: 43)

a visit entirely flash

'A lightning visit'

(17b) Au Tchad visite éclair et tout à fait inattendue (Noailly, 1990: 43) 
in Chad visit flash and totally unexpected

'In Chad, lightning visit and totally unexpected'

(18) un fait divers

a fact diverse

'news in brief'

(18a) *un fait très divers

a fact very diverse

(18b) *un fait divers et intéressant

a fact diverse and interesting

While we cannot go into these constructions in more detail here, we agree with Noailly that nominal groups in $\mathrm{N}+\mathrm{N}$ have some characteristics that are not normally associated with compounds. A recent and detailed analysis of $\mathrm{N}+\mathrm{N}$ constructions can be found in Picone (1996).

Combinations of a verbal root and a noun, such as gratte-ciel 'sky-scraper' and porte-parole 'spokesman' form another very productive type of compounds in French and in other Romance languages, such as Spanish, but this type hardly exists in Dutch or other Germanic languages. ${ }^{\mathrm{x}}$ These compounds, sometimes referred to as verbcomplement compounds (Fleischer, 2000: 890) have been studied by many authors, because they are different from other compounds, in that they do not have a head. For gratte-ciel, for example, neither gratte-nor ciel can be considered to be the head of this compound. Instead, some authors assume that for these so-called exocentric compounds, an external element, often a phonologically unrealised noun, such as bâtiment 'building' in the case of gratte-ciel or personne 'person', in the case of porte-parole, functions as its head. Because exocentric compounds do not have a head, DiSciullo \& Williams (1987: 79) do not consider them as compounds at all, but as syntactic constructions that are reanalyzed as words (or word-internal phrases), which are to a certain extent fixed. Zwanenburg (1992a) adopts this analysis and does not consider these constructions as real compounds either. 
In Dutch, $\mathrm{V}+\mathrm{N}$ compounds exist too, but they are not exocentric, as one can see in kook+kunst 'cooking art, cookery' or woon+comfort 'living comfort, comfortable living', for which the right-hand element functions semantically and syntactically as the head.

\subsection{Linking phonemes}

Dutch $\mathrm{N}+\mathrm{N}$ compounds may contain a linking phoneme, which forms a link between the first and the second element of the compound. Schwa or -s can fulfil this function. Booij (2002a) shows that linking phonemes should not be mistaken for plural morphemes. They appear in compounds such as stad+s+raad 'city council' or zonn+e+schijn 'sunshine', where the schwa or the $-\mathrm{s}$ cannot be interpreted as a plural because there is only one sun and the council belongs to only one city. There are however examples of Dutch compounds which do contain a regular plural form as their left-hand element, such as steden+raad 'cities' council'. In French, linking phonemes do not appear in compounds.

\subsection{Adjectival inflection inside compounds}

In Dutch, adjectives inside compounds are invariable, as one can see in (19) - (20)

(19) zuur+kool 'lit. sour cabbage, Sauerkraut'

(20) groen+voer 'lit.green feed, rabbit food'

In phrases, by contrast, adjectives are inflected, as one can see in (21) - (22).

(21) zure wijn 'sour wine'

(22) groene jas 'green coat'

As the non-head of nominal compounds can also be phrasal, we do find inflected adjectives inside nominal compounds, as in (23) - (24) where AN sequences appear in the non-head position of the compound. 
(23) [blote-vrouwen] $]_{\mathrm{NP}}$ blad 'nude women magazine' (Booij, 2002a: 146)

(24) [hete lucht $]_{N P}$ ballon 'hot air balloon' (Booij, 2002a: 146)

In French, adjectives generally agree in gender and number with the accompanying noun, whether or not they are part of a compound, a syntactic phrase or a lexicalised expression, as one can see in (25) - (28).

(25) Blanche-neige 'lit. white snow, Snow white'

(26) blanc-bec 'lit. white beak/mouth, greenhorn'

(27) chemise blanche 'lit. shirt white, white shirt'

(28) vin blanc 'lit. wine white, white wine'

There are some apparent exceptions to this rule, as one can see in (29). Although terre is feminine, terre-plein is a masculine word.

(29) terre-plein xi 'lit. earth full, central reservation'

This example is somewhat different from the others, because terre-plein is a borrowing from Italian terra pieno 'filled with earth' (Petit Robert). In this construction pieno is the head and terra is the complement of pieno, while in examples (25) -(28) the noun is the head and the adjective the adjunct. In the latter cases, agreement between nouns and adjectives is expected, but not in the former cases where the adjective is the head and the noun is the complement.

In Brussels French, agreement between noun and adjective does not always take place, as Baetens Beardsmore (1971) shows. While agreement is regularly absent in predicative position, it can sometimes be absent in attributive position too, as we can see in (30).

(30) Dan kan ekik famille nombreux worden (Wiske, tape 64: 4)

Then can I family numerous become

'Then I can become a large family.' 
Furthermore, as is well-known, for some adjectives, such as rouge or fantastique, the masculine and feminine forms are identical in most varieties of French, and differences between singular and plural forms of adjectives are only visible in written language.

\subsection{Conclusion}

In this section we have seen that there are striking differences between the formation of compounds in Dutch and French. Therefore, it is interesting to see how the grammars of both languages interact to allow for the construction of mixed compounds and the insertion of French nominal groups in Dutch.

3. Mixed compounds and French nominal groups in Brussels Dutch

In Table 2 we can see that the largest group of the 96 insertions are combinations of a noun and a prepositional phrase (35), directly followed in frequency by combinations of a noun and an adjective (24). This can easily be explained on the basis of the fact that these are the most productive types of nominal groups in French (see section 2.3). There are 22 mixed compounds in total, and six neoclassical compounds that exist as such in French and occur in their original form in Brussels Dutch. In the following sections we will describe each category in some detail, trying to establish to what extent they are integrated into Brussels Dutch. A complete list of all nominal groups can be found in the appendix.

- insert Table 2 about here -

\subsection{Nominal groups of $\mathrm{N}+\mathrm{PP}$}


The largest group of insertions are those that consist of a noun and a following prepositional phrase, such as salle à manger 'dining room', point de vue 'point of view' and boîte aux lettres 'letter box'. The list would be far longer if street names had been included, as the indigenous inhabitants of Brussels use French street names in almost all cases, also when speaking Brussels Dutch. All these nominal groups can be translated into (Brussels) Dutch, and in most cases their Dutch translations are compounds:

eet+kamer 'dining room', gezicht $+s+$ punt 'point of view' and briev+en+bus 'letter box'. For some reason or other, the bilinguals prefer to use French expressions instead of these compounds, in the conversations we recorded. It is clear, however, that ability to form Dutch compounds is not an issue here: Dutch compounds are used abundantly in the conversations. Many of the nominal groups are relatively fixed expressions in French, some of which are listed in dictionaries, or names of institutions or buildings in Brussels.

As far as their integration into Brussels Dutch is concerned, the internal structure of the nominal groups looks French on the surface, but word order within the phrase is in conformity with French as well as Dutch: in both languages prepositional phrases can only be inserted in the position after the noun, as we can see in the contrasts between (31a) and (31b), and between (32a) and (32b).

(31a) Het huis in het bos

The house in the forest

(31b) *Het in het bos huis The in the forest house

(32a) La maison dans la forêt The house in the forest (32b) * La dans la forêt maison The in the forest house 
This means that word order within nominal groups of the type N+PP is compatible with both languages and not exclusively French. The pronunciation of the individual words is not entirely (Brussels) French either, as plural endings - if there are any - are Dutch (see below) and Brussels French pronunciation is heavily influenced by Dutch anyway (Baetens Beardsmore, 1971). The main stress of the nominal groups falls on the last syllable, which is compatible with French stress rules as well as with Dutch stress rules. Externally, however, the nominal groups function as Dutch elements in a Dutch structure: the determiner which precedes the nominal groups (and which forms their left-most element) is Dutch, and inflectional suffixes (which are the elements on the extreme righthand side), if there are any, are Dutch too. It is important to note that the determiner is Dutch, as the determiner is the head of the Determiner Phrase of which the French elements form part. Dutch is thus not only the matrix language of the conversations, but also the matrix language of the phrase into which the French elements are integrated. This forms a strong indication that the French elements are to be considered as insertions (Muysken, 2000), but we will come back to this issue in section 4.

Some interesting points should be made regarding the morphological shape of the insertions. The large majority of the nominal groups are singular, but we have found a few examples ${ }^{\mathrm{xii}}$ for which an audible plural $-\mathrm{s}$ is attached to the extreme right of the phrase, as in (33) and (34), in apparent violation of the so-called No Phrase Constraint (Botha, 1984), which states that words are formed on a base of words and bound morphemes and not on phrases (see also DiSciullio \& Williams, 1987).

(33) bec de perroquets 'lit. beak of parrots, bone spurs' (34) réparateur de robinets 'lit. repairer of taps, plumbers'

It is important to see that this $-\mathrm{s}$ is Dutch and not French. In Dutch, plural is marked on nouns, at the extreme right-hand side, whereas in spoken French, plural is marked exclusively on the article which precedes the word or the phrase and not on the noun (Blanche-Benveniste, 1997: 140). In writing, the $-\mathrm{s}$ would be marked on the matrix nouns bec or réparateur, as in (35) and (36), and not on the embedded nouns perroquet or robinet. 
(35) becs de perroquet 'lit. beaks of parrot, bone spurs'

(36) réparateurs de robinet 'lit. repairers of tap, plumbers'

Although it would theoretically be possible to assume that an inaudible French plural is marked on the matrix nouns in these examples, this would mean that plural was marked twice on this phrase, as in (37) and (38), which is counter-intuitive as plural is generally allocated only once to an expression.

(37) ??becs de perroquets 'lit. beaks of parrots' (38) ?? réparateurs de robinets 'lit. repairers of taps'

It is interesting to note here that Vaugelas, in a discussion around the plural of arc-enciel, already notes that two plurals are not allocated to one compound (Rohrer, 1977). For Vaugelas, the correct plural form is arc-en-ciels, with a plural $-\mathrm{s}$ at the end of the compound, whereas the Petit Robert gives arcs-en-ciel, with an -s on the head noun. An irregular plural (arc-en-cieux) or two plural allocations (arcs-en-ciels) is excluded.

In French, when plural is marked twice on a phrase, only one of these functions externally in that agreement with the matrix determiner is established. In (39a), for example, agreement is established between the determiner une and the matrix noun boitte 'box' and not between the determiner une and the embedded noun lettres.

(39a) une boîte aux lettres 'lit. a box of letters, a letterbox' (39b) des boîtes aux lettres 'lit. ART boxes of letters, letter boxes'

In (39b) agreement is also established between the embedded determiner aux and the embedded noun lettres. In Dutch there are examples of a plural allocation to the head noun and its complement, as in (40).

(40) lucifers in doosjes (Booij, p.c.)

'matches in boxes' 
As we have noted above, in our corpus there are hardly any French nominal groups for which either the embedded noun or the matrix noun are overtly marked for plural. The only other example we have found is (41), for which (French) plural is marked on the determiner des which precedes Marolles.

(41) de bataille des Marolles 'the battle of the Marolles'

The $-\mathrm{s}$ on Marolles is not pronounced in this case. If a Dutch plural had been allocated too, it would have been a (scarcely audible) plural in schwa, rather than a plural in $-\mathrm{s}$, as the Dutch name for this part of Brussels is de Marollen (the final -n remains unpronounced). We assume that there is no Dutch plural on Marolles, and use the French spelling of Marolles in this example.

The appearance of inflection on phrases such as bec de perroquets is remarkable by itself, because in Dutch inflection generally does not appear on the right-hand side of phrases, but only on the matrix noun of a phrase, as we can see in the contrasts between (42a) and (42b) and between (43a) and (43b).

\begin{tabular}{|c|c|c|c|c|}
\hline \multirow[t]{2}{*}{$(42 \mathrm{a})$} & $\begin{array}{lll}\text { *slag in } & \text { de } \\
\text { shot in } & \text { the }\end{array}$ & \multicolumn{3}{|c|}{ luchten } \\
\hline & 'shots in the dark' & & & \\
\hline$(42 b)$ & slagen & de & lucht & \\
\hline & shot+PLUR & in & the & dark \\
\hline \multirow[t]{3}{*}{$(43 a)$} & $*$ duveltje & een & doosjes & \\
\hline & devil+DIM & in & $\mathrm{a}$ & box+PLUR \\
\hline & 'jack-in-the-boxes' & & & \\
\hline \multirow[t]{2}{*}{$(43 b)$} & duveltjes & in & een & doosje \\
\hline & devil+DIM+PLUR & in & $\mathrm{a}$ & box \\
\hline
\end{tabular}


In English, on the other hand, plural does appear at the end of some phrase-like compounds, as one can see in (44a) and (44b), in apparent contradiction of examples in (42) and (43).

(44a) jack-in-the-boxes

(44b) *jacks-in-the-box

Nominal groups such as bec de perroquet are imported as such into Dutch, and can receive a Dutch plural in either -en (pronounced as schwa) or $-\mathrm{s}$, just like native Dutch words or loanwords from French. Booij (2002a: 24) gives the following rule for the selection of either $-e n$ or $-s$.

(45) A plural noun ends in a trochee

In Dutch, according to Booij (2002a: 24) "the syllables of a word are preferably parsed into disyllabic left-headed feet, i.e.trochees. That is, both unparsed syllables and monosyllabic feet are less optimal than disyllabic feet." Thus, boek 'book' selects the suffix $-e n$ to form the plural boeken, and táfel 'table' selects an $-s$ to form the plural tafels. Examples (46) and (47) illustrate the application of the same principle to French borrowings in Brussels Dutch.

(46) témbers 'stamps'

(47) medikaménten 'medicines'

Some plural forms on borrowings in Dutch may reflect pluralisation patterns in French (Booij 2002a: 29). This could be the case in (46), for example. Although pluralisation of French borrowings in Brussels Dutch has not been studied in detail so far, De Vriendt (2001) shows that local allomorphs of the plural morpheme, such as -ne, which are different from those used in the Standard Dutch, can be found with some French borrowings, as one can see in (48) and (49). For more details on these allomorphs and for 
a discussion of their use with native Dutch vocabulary in Brussels Dutch, see De Vriendt (2001).

(48) pille $+n e$ (<Fr. pile, 'battery'), 'batteries' (De Vriendt, 2001: 10)

(49) caramelle+ne (<Fr. caramel) 'caramels' (De Vriendt, 2001: 10)

With some nouns, plural forms in $-s$ and in $-e n$ occur alternatively, which is possible for some native Dutch nouns as well, as in (50) and (51).

(50) commies+es 'shopping' (from French commissions)

(51) commies+en 'shopping' (from French commissions)

In conclusion, the data presented in this section show that inflection can appear on nominal groups such as bec de perroquets, and similar expressions, when inserted into Dutch. This can be interpreted as a sign that nominal groups in N+PP are often lexicalised. A further analysis of the status of these nominal groups is given in section 5 .

\subsection{Nominal groups of $\mathrm{N}+\mathrm{A}$ and $\mathrm{A}+\mathrm{N}$}

The following category is that of nominal groups which consist of a noun and an adjective $(\mathrm{N}=24)$, such as sens unique 'one-way street', or an adjective and a noun $(\mathrm{N}=$ 3), such as franc bourgeois 'free citizens', where the former are far more frequent than the latter, which is simply a reflection of the fact that nominal groups in $\mathrm{N}+\mathrm{A}$ are far more frequent in French than nominal groups in A+N (Mathieu-Colas, 1996). These nominal groups differ from the groups which contain a prepositional phrase because their internal structure is clearly not Dutch. Adjectives are placed before the noun, and not after the noun in Dutch. As far as the integration of the entire group into Dutch is concerned, the situation is very similar to that of the nominal groups in N+PP: a Dutch article functions as the head of the group and a Dutch plural can be attached to the right- 
hand side element, as we can see in (52) - (54), where an audible plural $-s$ is attached to the right-hand side of the phrase.

(52) de journal parlés 'lit. the newspaper spoken, radio news'

(53) de franc(s) bourgeois 'lit. the free citizen, citizen'

(54) de bon(s) vivants 'lit. the good living, jovial fellows'

The plural form journal parlés reveals that the noun journal remains singular. In French, the plural form of journal is journaux. If plural had been allocated to the noun as well as to the right-hand side element, the nominal group would have been journaux parlés, which we do not find. According to De Vriendt (p.c.) sens unique 'one-way street' and congé payé 'annual paid holidays' can be pluralised in exactly the same way, with an audible $-s$ on the right-hand side element, as in (55a) and (56a). For sens unique, it is also possible to use the plural form in -en (pronounced as schwa), as shown in (55b).

(55a) sens uniques 'lit. direction unique, one way streets' (55b) sens uniquen 'lit. direction unique, one way streets' (56) congé payés 'lit. holiday paid, annual paid holidays'

It is remarkable that a Dutch plural suffix can be attached to phrases such as congé payé, for two reasons: first of all, adjectives do not normally receive plural inflection in Dutch, and second, this adjective is found in post-nominal position, which is not normally a position available to adjectives in Dutch (Geerts et al., 1984). This extraordinary situation can only be explained if we assume, as we did for the nominal groups in $\mathrm{N}+\mathrm{PP}$, that the nominal groups consisting of $\mathrm{N}+\mathrm{A}$ are no longer syntactic phrases, but lexical templates, which are borrowed as such in Brussels Dutch, and have a nominal status in that they receive a determiner and a plural suffix. Support for this analysis comes from Gross (1996: 32) who claims, correctly in our view, that adjectives in compounds are not modifiers of the noun, but that a noun and an adjective inside a compound such as fait divers 'news in brief' form a single unit or "une unité lexicale nouvelle" (see section 5 for a discussion). 
There are far fewer nominal groups where adjectives precede the noun, but they are pluralised in exactly the same way as those where the adjectives follow the noun. There is no evidence that franc in (53) and bon in (54) are plural forms, so we will assume they are singular.

It is also interesting to note that there is no agreement between the noun and the adjective in some cases, as in (57) and (58). The absence of agreement between nouns and adjectives is a well-known characteristic of the speech of some bilinguals in Brussels (Baetens Beardsmore, 1971), although it is more common not to find agreement in predicative position than in attributive position. The absence of inflection on adjectives in attributive position can also be interpreted as evidence that French grammar is somehow suspended in these nominal groups: French agreement rules are no longer accessible and, as a result, the adjectives are generally invariable.

(57) famille nombreux 'lit. family numerous, large family' (Standard French: famille nombreuse)

(58) salle marollien 'litt. hall maroll+ien, hall of the Marolles' (Standard French: salle marollienne)

In conclusion, it is clear that most of the nominal groups in $\mathrm{N}+\mathrm{A}$ and $\mathrm{A}+\mathrm{N}$ are fixed combinations, some of which can be found in dictionaries. Their internal structure up to the N' level is French, at least at the surface, whereas the Determiner, which functions as the head of the construction, is Dutch. As a result, the nominal groups function externally as Dutch phrases.

\subsection{Nominal groups in $\mathrm{N}+\mathrm{N}$}

There are eight nominal groups which consist of two juxtaposed nouns, which therefore belong to the category of the substantif épithète. They belong to different subtypes distinguished by Noailly (1990): those for which the second noun functions as a qualifier of the first noun, as in (59), where pêcheur is a qualifier of salade, whereas taverne and restaurant in (60) are co-ordinated. 
(59) salade pêcheur 'lit. salad fisher, fish salad'

(60) taverne-restaurant 'bar-restaurant'

Following Bierbach (1981: 167) we have classified aide-comptable 'assistant accountant' in this category, and not among the $\mathrm{V}+\mathrm{N}$ constructions, because aide has been used as a noun, with the meaning of person who fulfills the role of assistant since the thirteenth century. Thus aide-comptable is probably better seen as a nominal group in $\mathrm{N}+\mathrm{N}$.

Given the popularity of these nominal groups, it is somewhat surprising that there are not more examples in our corpus. Various explanations can be advanced to explain their relatively low frequency, but we think that the most likely reason is that the nominal groups in $\mathrm{N}+\mathrm{N}$ do not occur in all styles equally frequently. According to Noailly (1990: 170), they are particularly frequent in publicity slogans and in expressive prose, even though the phenomenon is not limited to written language only. Our data being exclusively oral, this may be one of the main reasons why the phenomenon is not so frequent. Another reason may be that many of these groups in $\mathrm{N}+\mathrm{N}$ are novel combinations. According to Backus (p.c.) novel words are likely to be formed using matrix language material, while CS tends to target existing expressions.

\subsection{Nominal groups in $\mathrm{V}+\mathrm{N}$}

There are only three examples of nominal groups in $\mathrm{V}+\mathrm{N}$ in our data set, which makes this one of the smallest groups of insertions. Among those found, presse-casserole 'pressure cooker' (standard French cocotte-minute) can illustrate the difficulties in classifying some of these nominal groups. It also possible to analyse presse-casserole as a compound consisting of $\mathrm{N}+\mathrm{N}$, because presse exists as a noun in French too. We agree with Bierbach (1981: 47) that it is often impossible to decide whether the first element of compounds is to be interpreted as a nominal or a verbal root. Bierbach considers compounds with presse- as $\mathrm{V}+\mathrm{N}$ compounds, and we will follow her choice here, even 
though presse-casserole differs from cases such as presse-citron 'lemon squeezer' because in the latter the noun is the complement of the action expressed by the verb, but this is not the case for presse-casserole. .iii $^{\text {. }}$

The relatively low frequency of this type of nominal groups remains difficult to explain. The fact that the nominal groups of this kind do not exist in Dutch, and that there is therefore no equivalence between the two languages on this point, may play a role. It is not a very convincing argument though, because nominal groups in N+A are very frequent in the data set, even though adjectives do not follow nouns in Dutch. It is not impossible that more nominal groups in $\mathrm{V}+\mathrm{N}$ would be found in a larger data set. De Clerck (1981) gives a few borrowed V+N compounds, such as cache-pot 'lit. hide pot, flowerpot holder' and cache-poussière 'lit. hide-dust, overall'. Thus, the phenomenon is not unknown in Belgian Dutch.

\subsection{Neoclassical compounds}

The data set contains a small number of French compounds which are formed on the basis of Latin or Greek roots, such as autostrade 'lit. car-way, motorway', autostop 'lit. car-stop, hitch-hiking' and bénévoles 'lit. well-want+PLUR, volunteers'. These compounds differ from the ones discussed earlier, because they contain at least one bound root, and in some cases, as in autostrade and bénévoles, there are only bound roots from a Latin or Greek origin, and no other stems. This phenomenon occurs in many European languages (Ten Hacken, 2000). It is interesting to note that there is an audible plural $-s$ on bénévoles, a phenomenon we have discussed above in 3.1. and 3.2. As in the cases discussed in previous sections, we analyse this $-s$ as a Dutch plural. All three compounds are right-headed, which confirms the analysis given by Zwanenburg (1992a), in his discussion of learned compounds.

3.6 Compounds consisting of a possessive adjective and a noun 
The case of masœur 'nun' differs again from all previous types, in that it consists of a possessive adjective -ma 'my' and a noun sœur 'sister' (see also Baetens Beardsmore , 1971: 386). The possessive adjective forms a unit with the noun, as one can see from the fact that these two elements occur together as a single lexical entity in combination with a Dutch article, as in (61).

(61) De weeskes met de masœuren

the orphans-DIM with the nuns

'The little orphans with the nuns'

This phenomenon is also found in matante 'lit. my aunt, aunt' and mononkel 'lit. my uncle, uncle', which do not occur in our corpus, but which are attested in Baetens Beardsmore and in De Clerck (1981). We have found a plural form in -s (masœurs) as well as a plural form in schwa (masœuren).

3.7 Mixed compounds

Table 3 shows that there are 22 mixed compounds in the data set, most of which are combinations of two nouns. This is not surprising, because $\mathrm{N}+\mathrm{N}$ compounding is the most productive type of compounding in Dutch (see section 2.3). As a matter of fact, there are only two combinations of a verbal root and a noun, tapisseer+werk 'wallpaper job' and tapisseer $+c o l$ 'wallpaper paste'. xiv The data contain one combination of a preposition and a noun: onder+taske 'lit. under cup, saucer'. All examples have main stress on the first element and the word order is adjunct - head in all cases.

Most of the compounds have a Dutch head, and a French adjunct, which may be due to the fact that Dutch is the base language of the conversations in which these mixed compounds were recorded. This confirms Muysken's (2000: 150) observation that the head of most of mixed nominal compounds in Clyne's Australian English-German corpus is German, because the base language of the conversations is German rather than English. In a study of mixed compounds in various Belgian Dutch dialects, Weymare (2002) 
confirms that compounds with a Dutch head are the most frequent category of mixed compounds.

- insert Table 3 about here -

The mixed compounds can be divided in three groups: the first group consists of compounds with a French adjunct and a Dutch head, such as velo+winkel 'bicycle shop', which is the largest group; the second group contains compounds with a Dutch adjunct and a French head, such as winter+paletot 'winter coat', and the third group consists of a French adjunct and a French head, such as gazetten+marchand 'newspaper agent'.

It is not difficult to see that the word order within the compounds conforms to Dutch rules, in that they are head-final in all cases. As far as stress patterns are concerned, for all three groups it is true that the main stress falls on the first element, as is common for Dutch compounds. Note that this is also the case for the last group, which consists of French lexical items only. Contrary to nominal groups such as sens unique or salade pêcheur, the items in group three do not exist as such in French, but have been created in Dutch, on the basis of French elements, but using Dutch word order and Dutch stress patterns. This shows that the French elements in the compounds have been completely integrated into Dutch, from a morpho-syntactic point of view. If anyone wanted to use gazetten+marchand in Standard French, the expression would have to be transformed to a regular N+PP nominal group, for example vendeur de journaux 'lit. seller of papers'.

It is interesting to observe that some mixed compounds contain a linking phoneme, again typical of Dutch compounds (see section 2.4). Thus, lain $+e+$ matrassen 'woollen matresses', pill+e+lamp 'pocket lamp on batteries' and honn $+e+$ bain + ske '(small)dog bath' contain a schwa which links the two elements of the compound. We do not have examples of compounds which contain an $-\mathrm{s}$ as a linking phoneme, but Weymare (2002) found a couple of examples where $-\mathrm{s}$ is used as a linking phoneme: doleir $+s+$ mes 'shaver' and akkapareur $+s+v e s t$ 'vest with a lot of pockets'. The occurrence of linking phonemes, even in mixed compounds of type 3, which contains 
only French elements, is another indication of the complete integration of the French elements in a Dutch structure. We should not forget to mention that an important aspect of these compounds is that most of the French elements in the compounds tend to be established borrowings, which can occur as independent loanwords in Brussels Dutch or in Belgian Dutch as well. This is the case for example for preuve 'proof', which occurs independently as a loan word in our corpus, as well as in the compound preuve+stuk 'piece of evidence', cf. (62):

(62) A ja da was een preuve hein (Catherine, tape 7: 39)

'Ah yes, that was a proof, you know.'

Poplack (1990: 38) defines established loanwords as words that "typically show full linguistic integration, native-language synonym displacement and widespread diffusion, even among recipient language monolinguals." Words like velo, marchand and gazet clearly fall in this category, as they are are part of the everyday vocabulary used by the speakers of Dutch in Brussels (and elsewhere in Belgium). The (northern) Dutch equivalents fiets, handelaar and krant are unknown, certainly in Brussels. In many respects velo, marchand and gazet behave as Dutch words: Marchand can be combined with other Dutch words to form a variety of compounds (kolen+marchand 'coal merchant', wijn+marchand 'wine merchant' etc.). In all these cases marchand functions as the head of the compound, despite the fact that it is a French word. The same is true for gazet. De Clerck (1981: 137) gives, for example, gazet+papier 'newsprint', gazet(ten)+praat 'newspaper language'. As far as their pronunciation is concerned, there is some variation in the pronunciation of borrowings, and very little research has been done into the phonological integration of French loanwords. It is clear that marchand can be pronounced in different ways, but in most cases, the nasal vowel is replaced by the oral vowel [a] followed by $[\mathrm{n}] .^{\mathrm{xv}}$ Other indications of phonological integration can be found in the pronunciation of the first sound of gazet is in many cases a voiced velar fricative, as is common in Brussels Dutch. ${ }^{\text {xvi }}$ For some loan words, for example paletot, the main stress appears to have shifted to the first syllable, which is another sign of integration into Dutch. 
As some words appear to be completely integrated into Dutch, one may wonder to what extent the speakers are still aware of the fact that these are originally French. Words such as paletot, which do not contain any typically French phonemes and have main stress on the first syllable, may well be perceived to be completely Dutch. If so, it may even follow that these words can no longer be considered to be mixed compounds, at least from a synchronic point of view.

One mixed compound in our list, toile cirée fabriek 'oil cloth factory', deserves to be mentioned in particular because the left-hand side element consists of a nominal group in N+A. Although it is well-known that phrases can form the left-hand element of a compound in Dutch (Booij, 2002a: 146), this example shows that the internal structure of the left-hand side phrase does not need to conform to Dutch rules. Dutch normally does not allow adjectives to occur after the noun. Thus, the French elements form a small island of French grammar within the compound. This is perhaps less surprising if we recall that nominal groups in $\mathrm{N}+\mathrm{A}$ can also appear outside the compounds, as lexicalised phrases in a Dutch sentence, as we saw in section 3.2.

De Clerck (1981) and Weymare (2002) give one mixed compound which does not occur in our corpus, but which displays an interesting characteristic, and therefore deserves special attention. In travó $+\operatorname{man}^{x v i i}$ and travó+werker 'construction worker, builder' the French irregular plural form travaux 'work+PLUR', spelt travo, forms the left-hand side of the compound. ${ }^{\text {xiii }}$ The fact that an irregular plural form occurs within a compound is in accordance with the constraint on pluralisation in compounding which was first formulated by Kiparsky (1982) within his theory of Level Ordering, and later empirically tested by Gordon (1985), Alegre and Gordon (1996) and others. This constraint specifies that irregular plurals such as teeth as in teeth marks can occur within compounds (because irregular plurals are listed in the lexicon, and considered to be included at level 1 in the level ordering). As regular inflection is a level 3 process, it does not apply inside compounds, but only on the outside. Thus, regular plurals, such as claws cannot appear in compounds and *claws marks does not occur.

It should be noted that while travó in travóman is originally a French plural (<French travaux), one also finds the plural form travó 's. According to De Clerck (1981), in Belgian Dutch travó has been reinterpreted as a singular, and a regular plural travó 's 
can be formed on the basis of this singular form. This regular plural form is not used inside compounds.

To my knowledge, there are no clear examples of French-Dutch compounds containing regular French plural forms. It is very difficult - if not impossible - to find these, because the $-\mathrm{s}$ plural is not pronounced in French. One could theoretically argue that bougie+fabriek should be spelt as bougies + fabriek and toile cirée fabriek as toiles cirées fabriek, but there are no compelling reasons to consider the left-hand element as a plural form.

4. Borrowing, code-switching or code-intermediate phenomena?

At the beginning of this article, we asked the question whether mixed compounds and French nominal groups in Brussels Dutch are to be seen as code-switches or as borrowings. From the discussion in 3.7 it is clear that the mixed compounds can probably be considered as borrowings, even though they display some characteristics that distinguish them from classical borrowings. On the one hand, many mixed compounds are listed in dictionaries, rather than 'on the spot creations', and this is typical for borrowings. Most of the French elements inside these compounds are also established borrowings, listed in dictionaries, widely used in the community and integrated into Dutch, the matrix language. French words that are unintegrated into Brussels Dutch and that are not wide-spread the community do not occur in mixed compounds. On the other hand, the mixed compounds differ from classical borrowing in the sense that only half of the word is borrowed, whereas the other half is Dutch. In the case of mixed compounds which consist of two French morphemes, it is even more difficult to consider these words as borrowings, because these compounds do not exist as such in French.

The nominal groups differ clearly from the mixed compounds for a number of reasons. First of all, they are only partly integrated into Brussels Dutch, because the internal structure of some nominal groups, in particular the groups in $\mathrm{N}+\mathrm{A}$, is not Dutch. Second, the elements inside the nominal groups are generally not listed in Dutch dictionaries (except for some exceptions such as congé): they are therefore not 
established loans in (Brussels) Dutch. From this, we may conclude that they are probably unsuitable candidates for forming a mixed compound. Instead they are being used in a French context, in a construction that resembles a French phrase in many respects, except for the determiner and the plural form.

For theories of code-switching and borrowing these facts are interesting because they show that there may be some intermediate categories between classical borrowing and classical code-switching. In this respect it is interesting that Picone (1994: 326), in his analysis of English elements in Louisiana French argues for the existence of "codeintermediate or code-neutral phenomena wherein the grammatical apparatus of neither language is fully invoked." The current data differ however from Picone's data in that there is clear evidence for integration into Dutch in the form of Dutch determiners preceding the insertions, and Dutch plural markers for a number of French nominal groups. It should be kept in mind, however, that only a few items display these plural markers. There is also some evidence of lack of agreement between $\mathrm{N}+\mathrm{A}$ in nominal groups. One could therefore argue that the morphological apparatus of the two languages is not always fully operational, which would make the examples more similar to those presented by Picone.

While mixed compounds resemble classical borrowings in many respects, insertions of nominal groups are somewhat less like ordinary loanwords, in that they consist of more than one word and they are not listed in Dutch dictionaries, even though some of them may be collocations in French and thus be listed in French. Because they are partly integrated and partly unintegrated, they form an intermediate category between code-switching and borrowing. In other words, the patterns we have studied here can be seen as evidence for the fact that there is a continuum from borrowing to code-switching, cf. Table 4.

-insert Table 4 about here-

Muysken's (2000) approach to bilingual speech helps to shed new light on the similarities between the properties of what is traditionally called lexical borrowing and code-mixing. All nominal groups we have studied in this chapter can be considered as 
examples of insertional code-mixing . The nominal groups in (1) - (3) qualify as insertions on all the diagnostic criteria, because, first of all, they are single constituents, and second, the fragments preceding and the fragment following are grammatically related. This can very clearly be seen in (1), where the particle mee- 'with', which occurs at the end of the sentence, belongs to the verb neem 'take'. This verb has been moved to the second position in the sentence, leaving the particle in the original sentence-final position. Thus, the insertion carte d'identité is clearly nested in between two stretches of discourse that are grammatically related and unambiguously Dutch. Third, the French elements are content words rather than function words, and fourth, they are selected elements (objects or complements), which is also the case in (1) - (3). Finally, as we shall see below in more detail, the mixed compounds and the nominal groups are morphologically integrated into the base language, Dutch, even though some appear to be more integrated than others.

The mixed compounds are probably also best seen as examples of insertional codemixing. As we have seen in section 2, the rules for compounding are very different in French and Dutch. Thus, it would be difficult to analyse these as examples of congruent lexicalisation, as Muysken (2000: 150) proposes for the German-English nominal compounds described by Clyne (1967). In German-English compounds such as beach+häuser 'beach houses' (Clyne, 1967: 34), elements of two languages are inserted into a shared grammatical structure, which is typical for congruent lexicalisation. In the case of the French-Dutch compounds there is no such shared structure. In addition, the linking phonemes in the mixed compounds show that the overall frame of the compound is Dutch rather than French. The French elements are thus embedded into Dutch. There is some evidence of bidirectionality, which is not expected perhaps, even though the majority of the mixed compounds have a Dutch head. One possible explanation can be that speakers may no longer be aware of the fact that words like velo or paletot that appear inside these compounds are originally French, which could perhaps make it easier to use them as heads in right-headed mixed compounds.

It is important to note in this context, that the Brussels-Dutch corpus also contains examples of alternational code-mixing (see Muysken, 2000: 96 for more details), which 
typically consist of several constituents in a row. In this type of code-mixing, the sequences are non-nested, and often peripheral, as in (63).

$\begin{array}{lllllll}\text { Bij mijn } & \text { broer } & y & a & \text { un } & \text { ascenseur en } \\ \text { At my } & \text { brother's } & \text { there has an } & \text { elevator } & \text { and } \\ & & & & & \\ \text { alles } & & & & \\ \text { everything } & \end{array}$

"At my brother's place, there is an elevator and everything." (Treffers-Daller, 1994: 204)

Thus, the data in this corpus provide evidence for the unified theory of bilingual speech as presented in Muysken (2000).

5. Constructional idioms: a new view of insertions of nominal groups

At the beginning of this article, we noted that the French nominal groups such as carte d'identité that are inserted into Dutch are neither single words, nor complete constituents, but something in between: an intermediate projection, which can only function in a sentence through the combination with a (Dutch) determiner head. For theories of code-switching these units raise interesting questions, as we have seen above, because they challenge traditional distinctions between code-switching and borrowing. Outside the field of language contact studies, the status of nominal groups has also been discussed extensively among researchers with an interest in the interface between syntax, morphology and the lexicon. For many observers it is clear that these nominal groups form units of some kind and are not to be seen as regular syntactic phrases. Gross (1996: 32), for example, claims that adjectives in compounds such as fait divers 'news in brief' are not modifiers of the noun, but that a noun and an adjective inside a compound such as 
fait divers form a single unit or "une unité lexicale nouvelle". It remains unclear though, in his analysis what the nature of this new lexical unit is.

Recently new analyses of these constructions have been proposed that can help clarify the status of what we have called nominal groups. Booij (2002b: 302) shows that in English and Dutch noun phrases of the type $\mathrm{A}+\mathrm{N}$ can be seen as constructional idioms or lexical templates, that is "syntactic constructions with a (partially or fully) noncompositional meaning contributed by the construction, in which - unlike idioms in the traditional sense - only a subset (possibly empty) of the terminal elements is fixed." AN phrases often have the status of classificatory lexical expressions: they provide the name for a particular class of entities for which the language user needs an expression. This is the case in Dutch for example for dikke darm 'large intestine' and vrije trap 'free kick'. These expressions have to be listed in the lexicon because they are the conventional names for these entities. An important point is that the class of AN phrases is not closed: the class can be readily extended as soon as the need arises to name something. Therefore the claim is that the lexicon should contain a constructional idiom of the type $[\mathrm{AN}]_{\mathrm{NP}}$, which has two open positions, and no terminal element fixed. Constructional idioms have a number of interesting properties which show that they are lexicalised units rather than syntactic phrases. In AN phrases, for example, the adjective is always a bare A, without modifiers. In other words, in this kind of idioms, the lexical categories lose their normal projection possibilities. While it is possible to coin a phrase such as een zeer dikke darm 'a very large intestine', which contains the modifier zeer 'very', this phrase refers not to a particular class of intestin but describes the properties of a single intestin. Thus, if we insert a modifier into the phrase, the phrase loses its classificatory function.

We would like to argue that the nominal groups in $\mathrm{N}+\mathrm{PP}, \mathrm{N}+\mathrm{A}, \mathrm{N}+\mathrm{N}$ and $\mathrm{V}+\mathrm{N}$ we found in Brussels Dutch should be seen as constructional idioms. In these cases, we are dealing with constructional idioms that have been imported from French and this is what makes them different from other constructional idioms that can be found more generally in Dutch. The following arguments may help clarify why we believe the nominal groups are to be seen as constructional idioms. 
First of all, it is important to see that most of the nominal groups that are imported into Brussels Dutch are recurrent and frequent in Brussels Dutch. In many cases, they have the status of classificatory lexical expressions (Booij 2002b). If speakers of Brussels Dutch use assistante sociale 'social worker' or journal parle 'radio news', then this is because these are the conventional, established names for these individuals or these entities among speakers of Brussels Dutch. Most of our informants do not know the Standard Dutch equivalents of these expressions and thus have no alternative but to use the French expressions. Second, the meaning of these expressions is generally not entirely predictable from its constituent parts. While some expressions, such as assistante sociale, may be seen as partially compositional, in that the expression refers to a particular type of assistant, the meaning of expressions such as journal parlé is entirely non-compositional: its meaning needs to be stored in the lexicon, because the phrase journal parlé does not refer to a particular type of newspaper but rather to a news programme that is broadcast on radio. Third, the inflection patterns we have analysed in previous sections clearly show that the nominal groups inflect like words rather than like phrases. This again is an indication of the fact that they are frozen expressions or lexical units rather than syntactic phrases. Fourth, hardly any of the nominal groups contain modifiers. While it is possible to coin a phrase such as assistante très sociale 'a very social assistant', if this phrase were to occur, it would not refer to the profession or class of social workers anymore, but would describe the properties of an individual assistant. Thus, the syntactic categories in the phrase have lost their normal projection properties. There are only three examples of nominal groups that contain modifiers, and these are given in (64) - (66), but in all cases these modifiers are an integral part of the proper names of the buildings or the institutions that the expressions refer to. The adjectives ancien 'old, former', général 'general' and royal 'royal' cannot be replaced with other adjectives.

(64) Ancien Hotel de Bruxelles 'the former Hotel of Brussels'

(65) Comité Général d'Action 'General Action Committee'

(66) Lycée Royal de Forest 'Royal Forest/Vorst Grammar School' 
Fifth, the set of items that can be imported into Brussels Dutch in this way is potentially unlimited: while our data set is limited to around 70 examples, we have also seen that most Brussels street names can be added to the list, and other new elements can equally easily be added whenever the need arises. Thus, the nominal groups we have analysed in this paper have many if not all properties of constructional idioms, as described by Booij (2002b).

The occurrence of French constructional idioms in Brussels Dutch represents an innovation in the lexical patterns that are available to speakers of this language, which is highly relevant for theories of language change. Through the regular importation of lexical material from another language in the form of phrases which have a particular internal structure that was unknown in the language thus far, new patterns can establish themselves in the receiving language. While these patterns may initially only be filled with words from the guest language, over time, native words may perhaps be used to fill the slots, at which point one can speak of convergence of both systems. It should be noted however, that in the case of Brussels Dutch, we have not found examples of Dutch lexical items in these constructional idioms, so that this stage is probably not reached (yet) in this language contact situation.

If the above scenario can be found to operate more widely in language contact situations, this is highly relevant for the discussion around mechanisms of contactinduced change in general and for the controversy around the existence of structural borrowing in particular (see also Backus, this volume). While some researchers doubt whether there are sufficient arguments for assuming the existence of structural borrowing (see Winford, 2003), the importation of constructional idioms is a possible mechanism through which structural borrowing or convergence is achieved. More research on the interface of lexical, morphological and syntactic patterns in code-switching is clearly necessary to shed further light on this issue. 
Bibliography

Alegre, M.A. and Gordon, P. (1996) Red rats eater exposes recursion in children's word formation. Cognition 60, 65-82.

Backus, A. (2003) Units in code-switching: evidence for multimorphemic elements in the lexicon. Linguistics 41 (1), 83-132.

Baetens Beardsmore, H. (1971) Le Français Régional de Bruxelles, Université Libre de Bruxelles, Institut de Phonétique, conférences et travaux 3. Bruxelles: Presses Universitaires de Bruxelles.

Beard, R. (1996) Head operations and head-modifier ordering in nominal compounds. Paper at the $70^{\text {th }}$ meeting of the Linguistic Society of America, San Diego. (Unpublished manuscript, Bucknell University, Lewisburg PA).

Bierbach, M. (1981) Die Verbindung von Verbal- und Nominalelement im Französischen. Tübingen: Gunter Narr Verlag.

Bisetto, A. and Scalise, S. (1999) Compounding: morphology and/or syntax? In L.Mereu (Ed.) Boundaries of morphology and syntax (pp. 31-48). Series IV - current issues in Linguistic theory. Amsterdam/Philadelphia: John Benjamins.

Blanche-Benveniste, C. (1997). Approches de la langue parlée en français. Collection L'essentiel français. Gap: Ophrys.

Bloomfield, L. (1933) Language. New York: Henry Holt.

Booij, G. (1999) The phonology of Dutch. Oxford: Oxford University Press.

Booij, G. (2002a) The morphology of Dutch. Oxford: Oxford University Press.

Booij, G. (2002b) Constructional idioms, Morphology, and the Dutch Lexicon. Journal of Germanic Linguistics 14 (4), 301-329.

Booij, G. and Van Santen, A. (1998) Morfologie: de woordstructuur van het Nederlands [Morphology: Dutch word structure]. Amsterdam: Amsterdam University Press.

Botha, R. (1984) Morphological mechanisms. Oxford: Pergamon Press.

Clyne, M. (1967) Transference and triggering: observations on the language assimilation of postwar German-speaking migrants in Australia. The Hague: Martinus Nijhoff.

Darmesteter, A. (1967) [reprint of corrected 1894 ed. ; First ed. 1874] Traîté de la formation des mots composés dans la langue française comparée aux autres langues romanes et au latin. Paris: Honoré Champion

De Clerck,W. (1981) Nijhoffs Zuid Nederlands Woordenboek. 's Gravenhage/ Antwerpen: Martinus Nijhoff.

De Vriendt, S. (2001) De meervoudsvorming in het Brussels. De Vlaamse woorden [Plural formation in Brussels Dutch. The Flemish words]. Brussels Dialect 41, AugustSeptember-October 2001, 6-10.

De Vriendt, S. and Goyvaerts, D. (1989) Assimilation and sandhi in het Brussels. Leuvense Bijdragen 78 (1), 1-93.

DiSciullio, A.-M. and Williams, E. (1987) On the definition of word. Cambridge Mass: MIT Press.

Fleischer, W. (2000) Die Klassifikation von Wortbildungsprozessen. In Booij, Geert, Lehmann, Chr. and Mugdan, J. (eds) Morphologie. Ein internationales Handbuch zur Flexion und Wortbildung. Volume 1. Berlin: de Gruyter, 886-897. 
Geerts, G. and Heestermans, H. (1984) Van Dale. Groot Woordenboek der Nederlandse Taal. 11th Edition.Utrecht/Antwerpen: Van Dale Lexicografie.

Geerts, G., Haeseryn, W., De Rooij, J. and Van den Toorn, M.C. (1984 first edition) Algemene Nederlands Spraakkunst (ANS) Electronic version: E-ANS. URL: http://oase.uci.kun.nl/ ans/. [Accessed 07/01/03].

Grevisse, M. (1993) Le bon usage. Grammaire française, refondue par André Goosse. 13ième édition revue. Paris: Duculot.

Gordon, P. (1985) Level ordering in lexical development. Cognition 21, 73-93.

Gross, G. (1996) Les expressions figées en français: noms composés et autres locutions. Collection 1'Essentiel français. Paris: Ophrys.

Kiparsky, P. (1982) From cyclic phonology to lexical phonology. In H. van der Hulst and N. Smith (eds) The structure of phonological representations (Part 1) (pp. 131-175). Dordrecht: Foris.

Lardière, D. (1998) Parameter-resetting in morphology: evidence from compounding. In M.-L. Beck (Ed.) Morphology and its interfaces in second language knowledge (pp.283305). Amsterdam: Benjamins.

Mathieu-Colas, M.(1996) Essai de typologie des noms composés français. Cahiers Lexicologiques 69 (2), 71-125.

M'Barek, N. and Sankoff, D. (1988) Le discours mixte arabe/français: emprunts ou alternances de langue? Revue canadienne de linguistique 33, 143-154.

Muysken, P. (1992) Indic mixed verbal compounds. ESF Network on Code-switching and Language Contact. Code-switching Summer School (pp. 195-208). Pavia (Italy), 912 September 1992,.

Muysken, P. (2000) Bilingual speech. A typology of code-mixing. Cambridge: Cambridge University Press.

Myers-Scotton, C. (1993) Duelling languages: Grammatical structure in Codeswitching. Oxford: Clarendon Press.

Noailly, M. (1990) Le substantif épithète. Paris: Presses Universitaires de France.

Picone, M. (1994) Code-intermediate phenomena in Louisiana French. In K. Beals et al (Eds) CLS 30. Papers from the $30^{\text {th }}$ Regional Meeting of the Chicago Linguistic Society. Volume 1: the main session, 320-334. Chicago: Chicago Linguistic Society.

Picone, M. (1996) Anglicisms, neologisms and dynamic French. Linguisticæ Investigationes: Supplementa 18. Amsterdam/Philadelphia: John Benjamins.

Poplack, S. (1980) Sometimes I 'll start a sentence in Spanish y termino en Español: Toward a typology of Code-switching. Linguistics 18: 581-618.

Poplack, S.(1990) Variation theory and language contact: concepts, methods and data. Network on Code-switching and language contact. Papers for the workshop on concepts, methodology and data. Basel, 12-13 January 1990, 33-65.

Poplack, S. and Meechan, M. (1995) "Patterns of language mixture: nominal structure in Wolof-French and Fongbe-French bilingual discourse", in L. Milroy and P. Muysken (eds): One speaker, two languages. Cross-disciplinary perspectives on code-switching, (199-232). Cambridge: Cambridge University Press.

Posner, R. (1997) Linguistic change in French. Oxford: Clarendon.

Rohrer, Chr. (1977) Die Wortzusammensetzung im modernen Französisch. Tübinger Beiträge zur Linguistik 78. Tübingen: TBL Verlag Narr.

Romaine, S. (1989) Bilingualism. Oxford: Blackwell. 
Sadock, J.M. (1998) On the autonomy of compounding morphology. In S.G. Lapointe, D.K.Brentari and P.M. Farrell (1998) Morphology and its Relation to Phonology and Syntax (161-187) Stanford: CSLI Publications.

Sankoff, D., Poplack, S. and Vanniarajan, S. (1990) "The case of the nonce loan in Tamil", in: Language Variation and Change, 2, 71-102.

Ten Hacken, P. (2000) Derivation and Compounding. In G.Booij, Chr. Lehmann and J. Mugdan (Eds) (2000) Morphologie. Ein internationales Handbuch zur Flexion und Wortbildung 1 (349-360) Berlin: de Gruyter.

Treffers-Daller, J. (1994) Mixing two languages: French-Dutch contact in a comparative perspective. Berlin: Mouton de Gruyter.

Weymare, E. (2002) Gemengde samenstellingen in het Vlaams [mixed compounds in Flemish (Southern Dutch)]. Unpublished paper, University of Nijmegen.

Winford, D. (2003) An Introduction to Contact Linguistics. Oxford: Blackwell

Wioland, F. (1991) Prononcer les mots du français: des sons et des rythmes. Paris: Hachette.

Zwanenburg, W. (1992a) Compounding in French. Rivista di Linguistica 4 (1), 221-240.

Zwanenburg, W. (1992b) La composition dans les langues romanes et germaniques: essuie-glace / windshield-wiper. Working Papers of the research Institute for Language and Speech OTS, University of Utrecht, no 13. 
Table 1

The internal structure of nominal compounds in Dutch and French

\begin{tabular}{|l|l|}
\hline Dutch & French \\
\hline Order modifier - head & Order head - modifier \\
\hline $\begin{array}{l}\text { Accent on first element of } \\
\text { compound }\end{array}$ & $\begin{array}{l}\text { Accent on second element of } \\
\text { compound }\end{array}$ \\
\hline $\begin{array}{l}\text { N+N compounding very } \\
\text { productive }\end{array}$ & N+N compounding not productive \\
\hline V+N compounding productive & $\begin{array}{l}\text { V+N compounding very } \\
\text { productive }\end{array}$ \\
\hline $\begin{array}{l}\text { Linking phoneme between both } \\
\text { elements of the compound }\end{array}$ & $\begin{array}{l}\text { No linking phoneme between both } \\
\text { elements of the compound }\end{array}$ \\
\hline $\begin{array}{l}\text { No inflection on adjectives } \\
\text { inside the compound }\end{array}$ & $\begin{array}{l}\text { Presence of adjectival inflection } \\
\text { within compounds/fixed phrases }\end{array}$ \\
\hline
\end{tabular}

Table 2. Overview of French nominal groups and mixed compounds in Brussels Dutch

\begin{tabular}{|l|l|}
\hline Type of construction & Frequency \\
\hline $\mathrm{N}+\mathrm{PP}$ & 35 (not including any street names) \\
\hline $\mathrm{N}+\mathrm{A}$ & 24 \\
\hline $\mathrm{A}+\mathrm{N}$ & 3 \\
\hline $\mathrm{N} 1+\mathrm{N} 2$ & 6 \\
\hline Neoclassical compounds & 6 \\
\hline Mixed compounds & 22 \\
\hline total & 96 \\
\hline
\end{tabular}


Table 3

Mixed compounds in Brussels Dutch

\begin{tabular}{|c|c|c|}
\hline $\begin{array}{l}\text { type } 1 \\
\text { French adjunct }- \text { Dutch } \\
\text { head }\end{array}$ & $\begin{array}{l}\text { type } 2 \\
\text { Dutch adjunct }- \text { French } \\
\text { head }\end{array}$ & $\begin{array}{l}\text { type } 3 \\
\text { French adjunct }- \text { French } \\
\text { head }\end{array}$ \\
\hline $\begin{array}{l}\text { lain+e+matrassen } \\
\text { 'woollen matrasses' }\end{array}$ & $\begin{array}{l}\text { been+marchanten } \\
\text { 'bone merchant' }\end{array}$ & $\begin{array}{l}\text { tapisseer+col } \\
\text { 'wallpaper paste' }\end{array}$ \\
\hline $\begin{array}{l}\text { preuve+stuk } \\
\text { 'piece of evidence' }\end{array}$ & $\begin{array}{l}\text { winter+paletot } \\
\text { 'winter coat' }\end{array}$ & $\begin{array}{l}\text { pille+lamp } \\
\text { 'battery lamp' }\end{array}$ \\
\hline $\begin{array}{l}\text { crème+pak+ske } \\
\text { 'ice cream box +DIM' }\end{array}$ & $\begin{array}{l}\text { (h)onne+bain+ske } \\
\text { 'dog bath +DIM' }\end{array}$ & $\begin{array}{l}\text { gazette+marchand } \\
\text { 'news agent' }\end{array}$ \\
\hline $\begin{array}{l}\text { velo+winkel } \\
\text { 'bicycle shop' }\end{array}$ & $\begin{array}{l}\text { wijn+marchand } \\
\text { 'wine merchant' }\end{array}$ & \\
\hline $\begin{array}{l}\text { frigo+bakken } \\
\text { 'fridge boxes' }\end{array}$ & $\begin{array}{l}\text { gemeente+taxe } \\
\text { 'council tax' }\end{array}$ & \\
\hline $\begin{array}{l}\text { tapisseer+werk } \\
\text { 'wallpaper job' }\end{array}$ & $\begin{array}{l}\text { vlieg+machien } \\
\text { 'aeroplane' }\end{array}$ & \\
\hline $\begin{array}{l}\text { allumette+duus } \\
\text { 'matchbox' }\end{array}$ & $\begin{array}{l}\text { kolen+marchand } \\
\text { 'coal merchant' }\end{array}$ & \\
\hline $\begin{array}{l}\text { pelle+patat }^{3} \\
\text { 'jacket potato' }\end{array}$ & $\begin{array}{l}\text { onder+taske } \\
\text { 'saucer' (lit. 'under cup') }\end{array}$ & \\
\hline $\begin{array}{l}\text { bougie+fabriek }{ }^{4} \\
\text { 'candle factory' }\end{array}$ & & \\
\hline $\begin{array}{l}\text { lacet+fabriek } \\
\text { 'lace factory' }\end{array}$ & & \\
\hline $\begin{array}{l}\text { toile cirée fabriek } \\
\text { 'oilcloth factory' }\end{array}$ & & \\
\hline
\end{tabular}

\footnotetext{
${ }^{2}$ In De Clerck (1981) we found pillamp, witout a linking phoneme.

${ }^{3}$ In De Clerck (1981) we found pelpatat, without a linking phoneme.

${ }^{4}$ Van Dale (1984) does not consider fabriek as a borrowing from French. It appears to have been constructed on the basis of a Latin root.
} 
Table 4. A continuum from borrowing to code-switching

\begin{tabular}{|c|c|c|c|c|}
\hline \multicolumn{3}{|l|}{ One word } & \multicolumn{2}{|l|}{ More than one word } \\
\hline $\begin{array}{l}\text { Classical } \\
\text { borrowing } \\
\text { (single word; } \\
\text { listed; } \\
\text { integrated into } \\
\text { borrowing } \\
\text { language) }\end{array}$ & $\begin{array}{l}\text { Mixed } \\
\text { compound with } \\
\text { Dutch head or } \\
\text { French head } \\
\text { (internal } \\
\text { structure Dutch; } \\
\text { listed) }\end{array}$ & $\begin{array}{l}\text { Borrowed } \\
\text { compound } \\
\text { (internal } \\
\text { structure } \\
\text { French; } \\
\text { listed) }\end{array}$ & $\begin{array}{l}\text { Insertions of nominal } \\
\text { groups without } \\
\text { determiners } \\
\text { (internal structure French; } \\
\text { multi-word expressions or } \\
\text { collocations, often listed) }\end{array}$ & $\begin{array}{l}\text { Code-switching } \\
\text { of entire DPs } \\
\text { (internal } \\
\text { structure } \\
\text { French; not } \\
\text { listed) }\end{array}$ \\
\hline marchand & $\begin{array}{l}\text { Velo+winkel } \\
\text { Wijn+marchand }\end{array}$ & $\begin{array}{l}\text { Presse- } \\
\text { casserole }\end{array}$ & $\begin{array}{l}\text { Accident de travail, sens } \\
\text { unique }\end{array}$ & $\begin{array}{l}\text { Un petit canari } \\
\text { doe geen vuil. } \\
\text { 'A small canari } \\
\text { doesn't make } \\
\text { anything dirty' } \\
\text { (Treffers-Daller } \\
\text { 1994, p.204) }\end{array}$ \\
\hline
\end{tabular}




\section{Notes}

${ }^{\mathrm{i}}$ We use the word "Brussels Dutch" for the regional variety of Dutch spoken in Brussels. This variety belongs to the Brabantic dialects, although local inhabitants often refer to it as "Flemish". We avoid this term because the term "Flemish" is used for different varieties of Southern Dutch.

${ }^{\text {ii }}$ As not all readers may be familiar with Dutch, we use a + to indicates the borderline between the two morphemes. This convention is used in CHAT (MacWhinney 2000) for this purpose. In Dutch the compounds are most often written together (without a hyphen).

${ }^{\text {iii }}$ In Standard French this pan would be called a cocotte-minute. In Brussels the term casserole à pression is used regularly (De Vriendt, p.c.), and presse-casserole is probably a creation of this particular speaker. The Brussels Dutch spelling of presse-casserole is preskasrolle. We have kept the French spelling to make the source of the borrowing more transparent.

${ }^{\text {iv }}$ The literal translations magasin de légumes and paletot d'hiver are not used.

${ }^{v}$ The Brussels Dutch corpus consists of 150.000 words, and contains approximately 4000 borrowings from French, that is $2.6 \%$ of these words are borrowings. In Brussels French, borrowings from Dutch are found far less frequently: there are 117 Dutch words $(0.29 \%)$ in the 50.000 Brussels French words of which our corpus consists. All speakers are bilingual in the sense that they use the local varieties of French and Dutch on a daily basis. A small number of informants also have some knowledge of the standard varieties of Dutch and French. The local variety of Dutch is the matrix language of many of the conversations we recorded, and most probably the matrix language of the sentences from which the mixed compounds and nominal groups were extracted, as can be seen in (1) - (3). Speakers differ from each other with respect to their competence in each language, but it is not possible to discuss their language repertoires in this paper. For more details, see Treffers-Daller (1994). For the present paper, only the Dutch

${ }^{v i}$ The description below is mainly based on the properties of compounding in Standard Dutch and Standard French, as no description of these aspects of the grammars of Brussels French and Brussels Dutch is available. For more details on Brussels Dutch, the reader is referred to De Vriendt (2001) and De Vriendt \& Goyvaerts (1989). It is not impossible that Dutch varieties differ slightly from each other with respect to morpho-phonological rules related to compounding, but we do not think that the differences are pertinent to the argumentation of this paper.

${ }^{v i i}$ Rohrer (1977) compares the intensity, pitch and length of compounds and phrases, eg. Le tissue-éponge enlève la poussière vs. le tissu éponge la poussière. No differences were found.

viii There are a few examples of street names in Brussels Dutch that display a phrasal structure that is similar to the one found in French street names, for example Steenweg op Ninove 'road to Ninove', where the noun steenweg 'lit. stone road; road' is followed by the prepositional phrase op Ninove 'on/to Ninove'. An alternative name, Ninoofse steenweg, which consists of an adjective and a noun, is also in use. Further research into the use of street names in Brussels will need to clarify whether any transfer from French is likely to have occurred here.

${ }^{i x}$ This figure is based on an unpublished paper of P.-A.Buvet.

${ }^{\mathrm{x}}$ It is interesting to note that some of these, for example couvre-chef 'headgear', are found as early as the twelfth century Bierbach (1981: 156).

${ }^{x i}$ I am grateful to Rodney Sampson for drawing my attention to this example.

${ }^{x i i}$ According to De Vriendt (p.c.) it is possible to attach a plural $-\mathrm{s}$ to other examples from the list in our appendix too (e.g. point de vues or salle à mangers)

xiii I am grateful to Wiecher Zwanenburg for drawing my attention to this issue.

xiv These two can also be analysed as $\mathrm{N}+\mathrm{N}$ if one assumes that the speaker actually refers to the word tapissier 'paperer', which is a noun referring to the person who carries out the wallpaper job. Some evidence for this analysis can be obtained from the existence of nouns such as Brussels Dutch masj+er+s+werk 'brickwork, masonry', where masjer refers to the bricklayer (i.e. the name of the worker), rather than the activity. If the verbal root masj- were the lefthand side of the compound, it would be masj+werk (De Vriendt. p.c.).

${ }^{\mathrm{xv}}$ Not all nasal vowels are replaced in the same way. In donc 'so' for example, the nasal vowel is maintained in Brussels Dutch. 
${ }^{x v i}$ In Brussels French [g] is also frequently pronounced as a velar fricative (Baetens Beardsmore 1971), and this is often seen as interference from Dutch.

${ }_{\text {xvii }}$ It could be argued that the second half of this compound, -man, is English rather than Dutch. As the pronunciation is Dutch, we assume this is a Dutch lexeme.

xviii Note that this case differs clearly from the case of journal parlés, discussed in 3.2, where the plural was marked at the right-hand side of the nominal group, and not on the head noun journal. 